Весна Половина

Љиљана Марковић

Универзитет у Београду

Филолошки факултет

polovina.v@gmail.com

ljiljana.markovic@gmail.com

https://doi.org/10.18485/ai_diskurs_pobede.2019.ch12 $81^{\prime} 42$

\title{
СЕМАНТИЧКО ПОЉЕ ПОБЕДЕ И ПОРАЗА У РАЗЛИЧИТИМ КУЛТУРНИМ КОНТЕКСТИМА
}

У раду се бавимо лексичким пољем које обухватају антоними победа и пораз у неколико типова писаног дискурса, пре свега новинског и књижевног и то у различитим срединама: српској, енглеској и јапанској. Анализа је урађена на одговарајућим језичким корпусима, у којима је посматран како шири тако и ужи контекст у којима се јављају ова два лексичка поља. Утврђено је да се у књижевности мање јављају лексеме из лексичког поља победе у смислу групне (националне, етничке, класне и сл.), а много више као обележје индивидуалног стања јунака, док се у новинском дискурсу тај однос показао нешто друкчијим.

Кључне речи: победа, пораз, дискурс, језички корпуси.

Пољеga и ӣораз у културолошком контексту у јапанској књижевности

Рат, победа и пораз осликавани су у јапанској књижевности од самих књижевних зачетака. Писменост у Јапану је све до средине 17. века била резервисана за об- 
разовану аристократију, па тако и теме које се обрађују, идејно удаљене од обичног човека - проблеми на двору, званичне преписке војсковођа, дневници дворских дама, али и било који други вид записивања, не само да представљају прве примере књижевности у Јапану, већ представљају, како и Сансом наводи у својој књизи Јайанска исйорија gо 1333 (Сансом: 1958) прве писане изворе јапанске историје. Као такви, ови извори нам служе као важан историјски извор и незаменљив корпус за проучавање јапанске књижевности, историје и културе.

Јапанску историју и културу обележило је присуство ратничке класе, самураја, а описивање самурајских ратничких подухвата честа је тема књижевности. Не само што је ова тематика популарна у јапанској књижевности, већ је нашла своју верну публику широм света који су, поред књижевног стваралаштва, прихватили и друге видове уметности са ратничком тематиком: филмове, манге, анимиране серије и сл.

Тематика рата, победе и пораза у јапанском уметничком стваралаштву обојена је филозофском нотом која наглашава идеологију - саму (не)оправданост ратовања, али и шта сами ратници мисле о својим војним походима. Самураји су били углавном писмени, читали су поезију, практиковали су зен будизам, неки од њих су се бавили и сликарством, записивали су своје подухвате и препричавали их, али се углавном видео уметнички и филозофски акценат у њиховом приповедању. Нису биле типичне сцене насиља већ би било описивано све оно што претходи једној борби и ономе што је уследило након борбе. Нису биле описиване ратне тактике и слично, већ филозофска превирања до којих је долазило код самих ратника пре саме борбе. 
Хеике моногатари - најзначајнији пример

ратне књижевности

Ово дело осликава један од најважнијих догађаја у традиционалној јапанској историји - Гемпеи рат (11801185). Дело приповеда историјску битку између два клана, Таира и Минамото, где је клан Генђи извојевао победу. Аутор овог дела је непознат. Причу су најчешће преносили слепи путујући свештеници, усменим путем, уз музику жичаног инструмента бива. По начину писања, види се да је особа која је записивала причу била високо образована.

У делу се говори се о поразу клана Хеике. Књижевни историчари сматрају да се није хвалило јунаштво, већ се на поетски начин описује поражена страна. Кроз тужне слике ратовања говори се о узалудности ратовања.

Модерна књижевност о победи и поразу

Модерна књижевност се углавном бави тематиком Другог светског рата. Како је у овом периоду Јапан пролазио кроз веома интензивне друштвене и културолошке промене, те промене су биле описане у контексту нових друштвених околности.

Иако има писаца који су писали конкретно о рату, као и у старијој књижевности, сама тематика рата никада није у фокусу радње. Оно што рат доноси са собом, укључујући све друштвене недаће, промене и свакодневне проблеме, у већем је фокусу него сама ратна тематика. 
Семантичко поље победе и пораза у контексту јапанског језика

Анализа семантичког поља у јапанском језику може се довести у везу са употребом јапанског писма. Идеограми - појмовно писмо у јапанском језику, носи семантичку нијансу која утиче на суптилне разлике у значењу речи. Такође, контекст у коме се речи користе разликује у великој мери од начина на који се одређена реч пише. Објаснићемо основне карактеристике јапанског писма и на који начин употреба идеограма може имати утицај на семантичко поље. Затим, на примеру сложеница које носе значење йобеga и йораз, као и на појединачној анализи употребе датих речи, представићемо семантичке разлике.

\section{Идеограми у јапанском језику}

Употреба идеограма као једног од писма у јапанском језику, као и у осталим далекоисточним језицима оставила је јако дубок траг. Странцима ће можда бити јако тешко да разумеју зашто би неко користио толико компликован систем за писање, али после јако кратког изучавања језика и писма, долази се до закључка да је оно толико везано за данашњи језик, да би прелазак на неко друго, лакше писмо довело до проблема у комуникацији, првенствено због полисемије.

Постоје примери, као што су у Вијетнаму и Кореји, где су реформом језика прешли на употребу алфабетског писма, што јако лепо функционише. С тим што се у Кореји, иако се не користе у свакодневној употреби, идеограми уче у школи као и раније. Нека озбиљнија литература за изучавање језика је исписана комбинацијом идеограма и корејског алфабета (хангул), јако слично јапанској употреби мешаног писма. 
С обзиром на сложеност писања идеограмима Јапанци су имали идеју да, са развојем слоговног писма, пређу да пишу искључиво каном, без идеограма, али ова идеја није заживела.

Описмењавањем Јапанаца и преузимањем идеограма у јапански језик је дошло доста речи из кинеског језика, чије би писање слоговним писмом било крајње непрактично. Идеограми су на један крајње посебан начин лексички обогатили јапански језик. Поред овога највећи проблем су речи које се исто изговарају а различито пишу и сходно томе имају различито значење. Ако би се те речи писале само каном или латиницом, било би јако тешко, односно немогуће одредити на коју се реч мисли, уколико она није употребљена у реченици.

\section{Комбиновано коришћење писма}

Јапанци данас користе мешано три писма: идеограме, хирагану и катакану. Мајирибун представља назив за комбиновање ова три писма, али првенствено је реч о идеограмима и хирагани. Са развојем слоговног писма, Јапанцима је постало лакше да користе писмо на овај начин, управо због природе јапанске граматике. Хирагана је омогућила да се граматички наставци у јапанском језику који је аглутинативни лакше записују, и самим тим је омогућен даљи развој јапанског језика (да су користили само идеограме, то би било немогуће, јер не би постојао довољно једноставан и јасан начин да се граматичке промене обележавају). Каном се такође пишу и помоћне речце, и још неке граматичке целине, за које можда и постоји идеограм, али је унапред утврђено да се пише каном.

Иако су идеограми неодвојиви део јапанског језика, кана писмо је омогућило свим странцима који крећу са 
учењем јапанског да брже крену са овладавањем јапанског језика. Многи уџбеници су исписани идеограмима од самог почетка, док су изнад исписана читања, што је добар начин да неко јако брзо научи да чита велики број идеограма, јер, ако би се исти идеограм јављао у тексту касније, не би било исписано читање, тако да би онај ко учи на врло суптилан начин био натеран да запамти како се нешто чита. Наравно, временом би се додавао све већи број идеограма, тако да би онај ко би учио могао јако брзо да шири свој вокабулар.

\section{Идеограми и вокабулар}

Једна заједничка карактеристика се јавља у скоро свим случајевима употребе идеограма: значење речи се може прецизније одредити у зависности од идеограма. Сваки идеограм има своје читање, у јапанском језику и више читања, може имати више кун, или више он читања, може имати и само једно кун или само једно он читање, али и поред тога идеограми имају своје значење. Јапанци су у почетку користили више идеограма да би записали своје речи, од којих би први одговарао по значењу и по звучној вредности, али други би се нашао у сложеници само да би употпунио звучну вредност речи коју је требало записати - без обзира на значење. Тако данас имамо кинеске сложенице у којима је најчешће први идеограм носилац значења, док други има само своју звучну вредност. 
Основне карактеристике јапанског језика и јапанског писма

Јапанска граматика има одређене карактеристике и по томе није претерано јединствена у свету. Иако је јапански језик изолат, морфологија и правила за синтаксу нису нешто што се не среће у другим језицима. Постоје одређене несугласице, односно више различитих приступа изучавању и класификовању граматичких целина и приступи се свакако разликују у зависности од тога да ли се граматика изучава у Јапану или у иностранству и да ли је она писана за Јапанце или за странце. У неким случајевима приступи су врло слични једни другима, односно што је програм озбиљнији, чак иако је за странце, не разликује се много од оног који је прављен за Јапанце.

$\mathrm{y}$ данашње време, са развојем интернета и разних компјутерских апликација које могу помоћи у учењу јапанског, понуда материјала из којих може да се учи далеко је већа него што је то био случај раније. Ово с једне стране олакшава и убрзава процес учења свим студентима, али треба бити посебно обазрив јер су многи материјали на интернету који су презентовани путем сајтова креирани на добровољној бази и често нису поуздани.

Хирагана се користи за обележавање фуригане - читања исписана изнад идеограма, писања речи које имају своје идеограме, али је правилима утврђено да се пишу хираганом, за бележење окуригане, означавање кун читања у речницима и у неким случајевима писање речи страног порекла.

Катакана се користи за писање речи страног порекла, назива држава (иако се државе могу писати и идеограмима), страних имена, назива флоре и фауне (сви називи флоре и фауне се такође могу писати и идеограмима и хираганом), означавање он читања у речници- 
ма, као и за наглашене делове текста, или неке битне информације (на пример у новинама). Катакана у Јапану има мало ширу примену него што би се то учинило странцима који уче јапански ван Јапана, али већ у дневним новинама се може видети да катакана има ипак мало ширу примену.

Анализираћемо семантички значења и колокације речи са значењем победити и изгубити. У овом контексту ће бити анализиране речи које нису само у вези са победом и губитком у рату. Речи које наводимо представљају део свакодневне лексике у јапанском језику и могу се користити у разним контекстима.

\section{Лексеме које означавају рат}

Речи, односно идеограмске сложенице које означавају рат имају слично значење, а нијансе ћемо анализирати преко значења идеограма које те нијансе представљају.

戦う(tatakau, борити се) - лексема носи значење борбе, али само у физичком смислу, не и у апстрактном. Такође, обухвата и значење ратовања.

戦争する (sensou suru, ратовати), 競争する(kyousou suru, такмичити се), 争う(arasou, свађати ce, расправљати се) - с обзиром да су обе речи сложенице и да имају један заједнички идеограм, што је уједно и трећи пример у овој групи који ћемо анализирати, њихово значење је слично, али речи не представљају синониме, већ квази-синониме (јап. 類義語, ruigigo). И у једној и у другој лексеми имамо исту нијансу коришћења и слично значење, али се речи не могу узајамно мењати као синоними. Рецимо, иако је природно на српском рећи за две особе које се не воле да „они ратују међусобно 
већ много година“, оваква реченица, са употребљеним глаголом sensou suru нема скоро никакво значење на јапанском језику. Иако се можда може схватити шта неко жели да каже, звучи неприродно. Међутим, и у лексеми која значи такмичити се (kyousou suru) имамо други идеограм који носи значење „свађати се, расправљати се“, али у овом случају тај „конфликт“ који означава овај други идеограм не носи неко посебно значење, већ је ту да семантички допуни реч; први идеограм свакако носи основно значење ове речи - такмичити се.

\section{Семантика лексема са значењем} „изгубити“ и „победити“

Прва разлика коју уочавамо у лексици је да постоје

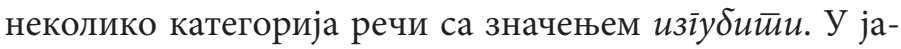
панском језику постоји јасна разлика између тога да ли се губи нека физичка ствар (nakusu) или је у питању значење йораз.

なくす (nakusu, изгубити) - лексема која означава да смо нешто физички изгубили, на пример, нешто што смо поседовали од ствари, али може да се односи и на особу коју смо изгубили. Реч нема конотацију губљења у виду пораза.

失う (ushinau, изгубити) - лексема која значи да смо нешто изгубили и може се односити и на нешто физичко и на нешто апстрактно. Такође, ни у овом случају, нема конотацију изгубити у контексту пораза.

損失 (sonshitsu, губитак) - ову лексему сачињавају два идеограма где први носи значење „штета“, а други идеограм, као што смо навели, има значење „изгубити“. Реч без већих нијанси означава губитак у виду профита и сл. Не носи другу конотацију. 
負ける (makeru, изгубити) - носи значење изгубити у смислу такмичења. Не може се користити у другим конотацијама (да смо изгубили нешто физички и сл.)

優勝 (yuushou, потпуна победа), 劣敗 (reppai, пораз слабијег) - у овом примеру имамо два антонима - један значи потпуна победа док је други потпуни пораз, односно пораз слабијег - такође речи које се користе само у контексту победе и пораза.

За разлику од српског језика, у јапанском језику не постоји колокација која у буквалном преводу значи „добити некога“ (у такмичењу, утакмици и сл.). Лексеме које следе означавају победу, али пошто постоје суптилне разлике, детаљније ћемо их анализирати.

勝利 (shouri, pobeda) - Лексема са значењем победа, без посебних конотација или ограничења у употреби. Граматички гледано је именица и користи се са глаголом する како би се формирао глагол.

ウイニングラン (uininguran, победничка прослава) Реч представља позајмљеницу из енглеског језика. Овакав концепт нам указује на то да реч не постоји у јапанском језику, већ се мора преузети као позајмљеница из неког страног језика, најчешће енглеског.

戦勝パレード (senshouparedo, победничка парада) Пре свега, ако погледамо реч 戦勝 (senshou), потребно је нагласити да се реч употребљава само у контексту победе у случају рата. У целости, у датом примеру, реч има мало модификовано значење. У овом случају имамо комбинацију речи победа и парада, где је реч парада страног порекла. Реч победа се може тумачити и као тријумф и може носити разне конотације. Можемо рећи, на пример, да смо победили неку земљу, без обзира на контекст односно да ли је реч о такмичењу или неком конфликту.

辛勝 楽勝 (shinshou; rakushou; победа) - обе речи су лексеме са значењем победа, међутим, обе речи су 
идеограмске сложенице које укључују два идеограма са значењем срећа. Битно је направити разлику да је у првом примеру срећа у конотацији да имамо среће, а у другом примеру да је нешто забавно (други синоним на српском језику је срећан сам). Први пример значи да смо имали среће што смо победили, односно, да је била тесна победа, док у другом примеру значи да смо лако победили (без велике муке).

勝利を収める (shouri wo osameru, однети победу, постићи успех) - у овом примеру можемо упоредити колокацију са српским језиком. Ако на српском односимо победу (такође, постоји пример и извојевати победy, с мало другачијом нијансом у значењу), у јапанском језику се чува победа (буквалан превод глагола osameru).

勝負ヴィクトリー (bikutorii) - позајмљеница из енглеског језика и лексема која такође означава победу. С обзиром на то да се пише писмом којим се записују речи страног порекла (катакана) и да то писмо не носи никакву конотацију, јер се не пише идеограмима, употреба речи није ограничена на контекст.

defeat (лат. diffacere, старофранцуски desfaire) у енглеском језику реч која означава пораз и носи неколико конотација. Може се односити на пораз у рату, пораз у мечу/утакмици/ или на такмичењу, лични пораз (апстрактно значење и сл.).

victory - реч која потиче из старофранцуског и носи значење победа. Такође, као и претходна реч из енглеског језика, може се употребити у неколико случајева и није ограничена на неку посебну конотацију. 
Поређење семантике у српском и јапанском језику

Јапански језик је аглутинативни језик који нема промене по падежима, род или број. Однос у речи у реченици се успоставља преко употребе помоћних речца које имају падешку функцију. Ова правила су унапред утврђена, односно унапред се зна који глагол прати која помоћна речца. У том смислу, не долази до граматичких одступања.

У српском језику можемо имати више предлога преко којих можемо довести у везу речи са значењем йобеgа и йораз.

Чињеница је да је глаголу (из)губити реакцијска допуна генитив с предлогом од, а не генитив с предлогом против. Томе је разлог чињеница што се уз глагол (из)губити генитивном допуном именује вршилац радње пасивне конструкције, који се у српском језику изражава готово искључиво формом од (стране) + генитив. Стога и нема нормативног оправдања за употребу генитива с предлогом против у датим конструкцијама. А шта је онда могло довести до употребе предлога против на месту језички утемељеног предлога од? Разлог томе највероватније јесте схватање датих конструкција као елиптираних (редукованих) с прелазном (транзитивном) вредношћу глагола (из)губити.

Други од глагола коме се приписује нормативна злоупотреба у синтагмама с предлогом против јесте глагол победити. Он је у значењској вези с глаголом изгубити, што је посебно очигледно ако се значења тих глагола посматрају у саодносу са значењима глагола поразити и именице пораз. Иако је, наиме, на први поглед парадоксално, ипак је неспорно да су глаголи победити и поразити синоними! Оба глагола су прелазни глаголи са истим вршиоцем радње у субјекту и трпио- 
цем у акузативном објекту: Партизан је победио Звезду и Партизан је поразио Звезду имају исто значење: Партизан је победник а Звезда поражени тим. Истост значења потврђује и пасивна трансформација реченице? Звезда је поражена/побеђена од Партизана. Реченица с глаголом изгубити могућа је само с пасивном перспективизацијом субјекта и објекта, дакле обрнутом од оне у реченицама с глаголима победити и поразити: Звезда је изгубила од Партизана. Глагол изгубити тако је антоним глаголима победити и поразити у реченицама у којима субјекат и објекат стоје у односу реципрочне супротстављености.

Тај однос се, међутим, значењски усложњава укључењем у анализу и значења именица победа и пораз изведених од глагола победити и поразити. Док су глаголи победити и поразити синоними, од њих изведене именице победа и пораз нису синоними, него антоними, што се види и по речничком одређењу њихових значења, где се победа дефинише као успех, а пораз као неуспех. Зато није ни чудо да глаголи победити и поразити деле структурно-семантичке особине, док се именице победа и пораз у тим карактеристикама потпуно разилазе. Наиме, при номинализацији реченице с транзитивним истим глаголом победити твори се неконгруентна именичка синтагма с генитивним предлогом против или инструменталним предлогом над као еквивалентом објекту, уп.: Партизан је победио Звезду $\rightarrow$ победа Партизана против Звезде/над Звездом.

При номинализацији реченице с прелазним глаголом поразити, уз навођење и победника и пораженог, ствара се неконгруентна именичка синтагма с генитивом с предлогом од којим се именује еквивалент, али не објекту него субјекту, уп.: Партизан је поразио Звезду $\rightarrow$ пораз Партизана од Звезде, па су те конструкције 
значењски супротне. Номинализована синтагма с именицом пораз за подлогу нема активну реченичну форму (Партизан је поразио Звезду), него пасивну (Звезда је поражена од Партизана). Из тога онда произлази да је именица пораз, иако изведена од глагола поразити, значењски еквивалентна том глаголу само у пасивној употреби. Значењски еквивалент у активној конструкцији именица пораз нема у реченици с глаголом поразити, него искључиво у реченици с глаголом изгубити: Звезда је изгубила од Партизана = пораз Звезде од Партизана. Глагол изгубити и именица пораз деле још једну заједничку карактеристику у конструкцијама реципрочне супротстављености: пасивна форма глагола изгубити неупотребљива је у тим конструкцијама (уп.: *3везда је изгубљена од Партизана), док синтагме с именицом пораз никад нису ни структурно ни семантички еквивалентне активним глаголским конструкцијама (уп.: Партизан је поразио Звезду $\rightarrow{ }^{\star}$ пораз Партизана против/са Звездом).

Због тога употреба генитива с предлогом против за обележавање вршиоца радње у конструкцијама с именицом пораз, баш као ни у конструкцијама с глаголом изгубити, нема никаквог ни структурног ни семантичког оправдања, па се зато и не може сматрати нормативно оправданом, и поред тога што су у новинама врло чести примери типа: Шкот је био на ивици пораза против [треба: од] Милоша Раонића (Политика, 31. 1. 2016, 35).

\section{Закључак}

Анализирајући пре свега културолошку позадину

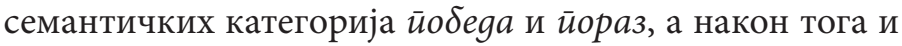


примере на јапанском, српском и енглеском, видели смо како културолошки контекст може играти битну улогу у правилној семантичкој употреби лексема. У случају јапанског језика посебну улогу игра и писмо које може модификовати значење речи и чак и ако је у суштини исто значење постоји ограничен избор контекста или колокација у којој реч може бити употребљена.

\section{Извори и литература}

Греј6 2009: Grabe, W. Reading in a Second Language, USA: Cambridge University Press, 2009.

Елис 2005: Ellis, N. "At the interface: Dynamic interactions of explicit and implicit language knowledg". Cambridge: Studies in Second Language Acquisition, 27 (2005): 305-52.

Елис 2006a: Ellis, N. "Language acquisition as rational contingency learning”. Oxford: Applied Linguistics, 27 (2006): $1-24$.

Елис 2006б: Ellis, N. "Selective attention and transfer phenomena in SLA: Contingency, cue, competition, salience, interference, overshadowing, blocking, and perceptual learning". Oxford: Applied linguistics, 27 (2006): 164-94.

Јукико 1995: Yukiko, S. Informative Japanese Dictionary. Japan:

Shinchosha, 1995.

Кинсич 1998: Kintsch, W. Comprehension: A framework for cognition. New York: Cambridge University press, 1998.

Конинг 2013: Conning, A. S. The Kodansha Kanji Learner's course. USA: Kodansha USA, 2013.

Марковић, Тричковић 2013: Марковић, љ. и Д. Тричковић. Канђи. Београд: Филолошки факултет, 2013.

Нанет 2005: Nanette, Gottlieb. Language and Society in Japan. UK: Cambridge University Press, 2005.

Онил 1973: O’Neil, P.G. Essential Kanji. Boston: WEATHERHILL, 1973.

Сансом: 1958: Sansom, G. A Japanese History to 1333. UK: Oxford University Press, 1958. 
Ћиеко и др. 1990: Chieko, Kano, Shimizu Yuri, Ishii Eriko. Basic Kanji

Book vol. 1 基本漢字 500, Japan: Bonjinsha CO. LTD, 1990.

Ћиеко и др. 1991: Chieko, Kano, Shimizu Yuri, Ishii Eriko, Basic Kanji

Book vol. 2 基本漢字 500, Japan: Bonjinsha CO. LTD, 1991.

Ћиеко и др. 1997: Chieko, Kano, Shimizu Yuri, Takenaka Hiroko, Ishii

Eriko, Akutsu Satoru, Hirakata Yukiko. Intermediate Kanji Book

vol. 1 漢字 1000 plus改訂版, Japan: Bonjinsha CO. LTD.

Ћиеко и др. 1997: Chieko, Kano, Shimizu Yuri, Takenaka Hiroko,

Ishii Eriko, Akutsu Satoru, Hirakata Yukiko. Intermediate

Kanji Book vol. 2 漢字 1000 plus改訂版, Japan: Bonjinsha

CO. LTD.

Ханас 1997: Hannas, W.C. Asia's ortographic dilema. Honolulu:

University of Hawaii Press, 1997.

Vesna Polovina

Liljana Marković

\section{THE SEMANTIC FIELD OF VICTORY AND DEFEAT IN DIFFERENT CULTURAL CONTEXTS}

The paper deals with the lexical field, which includes the antonyms of victory and defeat in several types of written discourse, primarily newspaper and literary, and more specifically, in different environments: Serbian, English and Japanese. The analysis has been carried out on the appropriate language corpora, in which both the broader and the narrower contexts in which these two lexical fields occur are observed. It has been found that lexemes from the lexical field of victory are less likely to occur in literature in terms of group (national, ethnic, class, etc.), and much more as a characteristic of the individual status of a hero, while in the newspaper discourse this relationship has proved somewhat differently.

Key words: the Victory, a Defeat, Discourse, Language Corpora. 